\title{
Reference Ranges of Trace Elements (Selenium, Zinc, Copper) in Tokat Province
}

\author{
Taner $\mathbf{A}^{1}$, Husamettin $\mathbf{V}^{2 *}$, Emine $\mathrm{NK}^{3}$, Fadime $0^{4}$ and Recep $\mathrm{G}^{5}$ \\ ${ }^{1}$ Department of Medical Biochemistry, Selcuk University, Turkey \\ ${ }^{2}$ Faculity of Medicine-Department of Medical Biochemistry, Selcuk University, Turkey \\ ${ }^{3}$ Department of Molecular Biology and Genetics, Necmettin Erbakan University, \\ Turkey \\ ${ }^{4}$ Department of Medical Biochemistry, Selcuk University, Turkey \\ ${ }^{5}$ Medical Faculty Hospital, Selcuk University, Turkey
}

\section{Thesis}

Volume 4 Issue 4

Received Date: November 20, 2019

Published Date: December 27, 2019

DOI: $10.23880 / \mathrm{ijbp}-16000170$

*Corresponding author: Hüsamettin Vatansev, Selcuk University, Medical School Department of Medical Biochemistry Konya, Turkey, Tel: +905055219555; Email: hvatansev@hotmail.com

\section{Abstract}

Objective: Trace elements copper, zinc and selenium, are found in extremely low amounts in living organisms but have extremely important functions for the organism. These elements take part in enzymatic reactions in the organism, structure of the bones, body growth and in many other vital functions. The aim of this study was to determine serum levels of selenium, zinc and copper in healthy individuals aged 18-65 years and people older than 65 years living in Tokat province.

Method: This is a descriptive cross-sectional study which was conducted as a master's thesis at Selçuk University Medical Biochemistry Laboratory. The sample size in our study was selected considering C28-A3 protocol of the National Committee for Clinical Laboratory Standards (NCCLS), randomly selected 159 healthy individuals aged 18-65 + years were included in the study. Reference interval for serum selenium levels were measured by atomic absorption spectrometer with Zeeman correction, serum zinc and copper reference intervals were measured by flame atomic absorption spectrometer. The analysis of the data was transferred to the computer environment through the Minitab14 statistical program and the related analyzes were performed for each variable.

Results: Of the 159 healthy subjects included in the study, 58 were female and 101 were male. Estimated mean reference values for serum selenium levels (geometric mean, GM) at 95\% confidence interval; $73.35 \mu \mathrm{g} / \mathrm{L}$ (70.35-76.35 $\mu \mathrm{g} / \mathrm{L}$ );

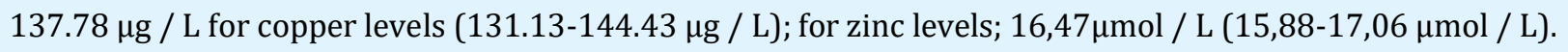

Conclusion: This study esatablishes reference values for serum selenium, zinc and copper levels in healthy adults living in Tokat province. Our results showed a discrepancy with the results' of other countries as reported in the literature. In addition our results suggests that reference values for trace elements are affected by regional differences.

Keywords: Trace Elements; Selenium; Zinc; Copper 


\section{International Journal of Biochemistry \& Physiology}

\section{Introduction}

Trace elements are vital minerals that are required in fair amount of daily consumption to maintain a healthy metabolism. trace elements, can be measured from body fluids and tissues [1]. Trace element sources found in nature varies regionally. Humans receive these elements through air, soil, environmental transport, nutrients and water. Changes in environmental or working conditions, as well as stress, can lead to changes in the absorption of trace elements. Technical food processing, soil fertilization or over-fertilization can cause significant concentration changes of trace elements in the foods [2]. Therefore, differences in the source of elements of each region create different compositions in living organisms [3]. Reference ranges and values are of great importance in helping clinicians to differentiate between sick and healthy individuals. As a result of the analysis performed by each laboratory, it is best to determine its own reference value for each analyte. Se, $\mathrm{Zn}$ and $\mathrm{Cu}$ are involved in many functions in the body. Trace elements such as zinc $(\mathrm{Zn})$, selenium $(\mathrm{Se})$, and copper $(\mathrm{Cu})$ protect cells against oxidative stress [4].

Se is a potent antioxidant that protects the body from free radicals and plays a role in the structure of glutathione peroxidase enzyme [5]. Adequate consumption of these trace elements helps prevention of diabetes and cardiovascular diseases, delays ageing, strengthens the immune system and decreases the risk of various cancer types by inhibiting tumor growth $[6,7]$.

Zinc; important in more than 300 enzymatic reactions such as DNA and RNA, carbohydrate metabolism and gene expression is involved in the structure of more than 2000 proteins. $\mathrm{Zn}$ is not found in free state in the nature, but in connected state. $\mathrm{Zn}$; It is an essential element for lymphocyte transformation and plays a role in visual functions, thyroid hormone homeostasis, wound healing, maternal and infant development during pregnancy, DNA repair, protein synthesis and glucose control. It has an effect on growth hormone, prolactin and thymic hormones. $\mathrm{Zn}$ reduces oxidative stress and helps protect the body from cancer by enabling the immune system to develop. Metabolic Zn requirements increases in periods such as puberty, pregnancy and breastfeeding $[8,9]$.

Copper is an essential trace element involved in many tasks as a biocatalyzer in human metabolism. It is a strong peroxidant element. $\mathrm{Cu} / \mathrm{Zn}$ is a component of superoxide dismutase and acts as a free radical scavenger. It catalyzes the oxidation of oils and ascorbic acid. It is plays role in protein synthesis, tissue regeneration, structure of the bones, ATP synthesis and hemoglobin synthesis. It is a necessary element for the development of the central nervous system [10].

The richest food containing selenium is fish and seafood. Fresh and canned tuna, mackerel and sea bass usually had $1 \mathrm{mg} / \mathrm{kg}$ selenium values [11]. Dried fruits like hazelnut and pine nut, soy beans, lentils and green peas have high levels of copper. Bitter chocolate has the highest amount of $\mathrm{Cu}$ as an ingredient [11].

High amounts of Zinc can be found also in meat and dairy products, grain and egg, but the highest values are found in pine nut, hazelnut and almond [11].

The aim of this study; The determination of selenium, copper and zinc reference values of Tokat Province, this is of great importance as it is the first study conducted in our country in regional level.

\section{Materials and Method}

\section{Criteria for Inclusion in the Study}

- The participants were asked whether they are feeling well today.

- Age range was 18-65 +.

- Partisipants were asked If there is a daily drug or vitamin intake, if it is the name and frequency of the dose was recorded and the if they allowed measurements to be taken.

- The use of drugs for the treatment of estrogen, oral contraceptives and hypothyroidism, previded that registration is permitted.

\section{Exclusion from Study Criteria}

- Diabetes treated with insulin or oral medication.

- Chronic liver or renal failure.

- The presence of blood results indicating an other serious disease.

- Hospitalization or illness in last 4 weeks.

- Blood donation with in last 3 months.

- HBV, HCV and HIV carriers.

- Pregnancy or having children under 1 year of age.

- Use of alcohol and tobacco products.

- The study was started in the last 12 weeks considering the participation of a research product or study. 


\section{International Journal of Biochemistry \& Physiology}

The NCCLS C28-A3 protocol recommends a sample size of at least 120 (male and female $60 * 2$ ) in the study area. In this study we conducted in Tokat province, NCCLS's C28-A3 protocol was taken into consideration and the sample size of our study consisted of 159 people, 101 males and 58 females between the ages of 18-85. Random venous blood samples were obtained from 159 healthy adults over the age of 18 (Table 1) living in and around Tokat between from June 2012 to June 2013. The samples were examined according to the allowance of the Selcuk University Research Ethics committee and the guidelines of NCCLS. Samples obtained were centrifuged at $5000 \mathrm{rpm}$ for 10 minutes, stored in the freezer at temerature $-80^{\circ} \mathrm{C}$ until the study day. On the day of analysis, the samples were kept in room conditions to adapt and were tested in Varian AA240 Zeeman corrected atomic absorption spectrometer for Se analysis and in flame atomic absorption spectrometer for $\mathrm{Zn}$ and $\mathrm{Cu}$ analysis. We also examined from samples routine hemogram,routine biochemistry and TSH analysis were also performed.

\begin{tabular}{|c|c|c|c|}
\hline Gender & Male & Female & Total \\
\hline $\mathrm{N}$ & 101 & 58 & 159 \\
\hline $\mathbf{\%}$ & 63.52 & 36.48 & 100 \\
\hline
\end{tabular}

Table 1: Distribution of individuals in terms of their gender.

\section{Selenium Analysis}

$200 \mu \mathrm{l}$ serum samples taken from the study tubes were placed in the Teflon tubes in order to deproteinize in the microwave oven. $800 \mathrm{uL} 0.1 \% \mathrm{HNO}_{3}$ was added to tubes, then $120{ }^{\circ} \mathrm{C}$ heat was applied at 220 bar pressure for 15 minutes.

They were allowed to cool to room temperature. 100 $\mu \mathrm{l}$ of resultant sample was added to $200 \mu \mathrm{l}$ of $0.1 \% \mathrm{HNO}_{3}$ for dilution and the samples were placed in tube spots. Measurements were obtained from Varian AA240 Zeeman corrected atomic absorption spectrometer at $196 \mathrm{~nm}$.

\section{Zinc and Copper Analysis}

$500 \mu \mathrm{l}$ of serum samples were taken and the solution was diluted by adding $2 \mathrm{ml}$ of $1 \% \mathrm{HNO}_{3}$. Resultant samples were used for copper and zinc measurements with heated atomic absorption spectrometer operated with acetylene gas. Copper measurement was performed at $324.7 \mathrm{~nm}$ wavelength and for zinc measurement at $213.9 \mathrm{~nm}$ wavelength.

\section{Statistical Analysis}

Datas acquired from specimens then transferred to a digital format via Minitab14 statistics program, further analysis were operated on this platform.

To perform further analysis in parametric method, the probability distribution of the reference group data was assumed to fit a normal distribution. Before the statistical analysis was performed, the data was tested for conformity with the Anderson-Darling test. Normally distributed variables were compared with the following models.

Variables Showing Normal Distribution were Compared with the Following Models

$$
\begin{gathered}
Y_{j}=\mu+e_{j} \\
\text { Hypothesis (There are no difference) }
\end{gathered}
$$

By the way

$Y_{j: \mathrm{y}}$ variable $j$. observation $\mu$ : overall average $e_{j}$ :Leftovers

$$
\begin{aligned}
Y_{\mathrm{ij}}=\mu & +F_{i}+e_{\mathrm{ij}} \\
& : \text { Hypothesis (There are difference) }
\end{aligned}
$$

$\mathrm{H}_{1}$

By the way

$Y_{i j}: Y_{i j}$ variable i: The group j: Observation $F_{i}: F$ factor $i$ : level of action $e_{\mathrm{ij}}$ : Leftovers

Logarithmic transformation was applied to variables that do not show normal distribution. Nonparametric tests were performed in cases where the variables did not show normal distribution as a result of transformation. Reference range limits were calculated based on the $95 \%$ center of normal distribution $(2.5 \%$ and $97.7 \%$ percentages). Parametric tests were used for the data showing normal distribution.

\section{Results}

The distribution of the participants according to age, gender, smoking and exercise startus were given in Table 2. 


\section{International Journal of Biochemistry \& Physiology}

\begin{tabular}{|c|c|c|c|}
\hline & Selenium $(\boldsymbol{\mu g} / \mathbf{L})$ & Zinc $(\boldsymbol{\mu m o l} / \mathbf{L})$ & Copper $(\boldsymbol{\mu g} / \mathbf{L})$ \\
\cline { 2 - 4 } & (Average \pm SD) & (Average \pm SD) & $130.5 \pm 51,52$ \\
\hline Female & $73,37 \pm 14,73$ & $15.47 \pm 3,90$ & $126.0 \pm 35,63$ \\
\hline Male & $73,44 \pm 23,12$ & $17.06 \pm 3,85$ & $128.5 \pm 99,42$ \\
\hline Smoker & $72,68 \pm 19,96$ & $16,14 \pm 3,56$ & $127.0 \pm 119,77$ \\
\hline Non smoker & $73,80 \pm 20,98$ & $17,13 \pm 4,51$ & $127.0 \pm 68,95$ \\
\hline Exercise & $80,05 \pm 20,13$ & $16,15 \pm 4,05$ & $128.0 \pm 112,27$ \\
\hline Non-exercising & $72,65 \pm 28,6$ & $16,55 \pm 3,22$ & $126,0 \pm 38$ \\
\hline $\mathbf{1 8 - 2 9}$ & $76,47 \pm 18,17$ & $16,45 \pm 3,8$ & $128,0 \pm 51$ \\
\hline $\mathbf{3 0 - 3 9}$ & $74,43 \pm 19,36$ & $16,16 \pm 3,8$ & $153,0 \pm 53$ \\
\hline $\mathbf{4 0 - 4 9}$ & $73,96 \pm 17,48$ & $17,44 \pm 3,8$ & $161,0 \pm 36$ \\
\hline $\mathbf{5 0 - 6 4}$ & $69,06 \pm 17,03$ & $16,12 \pm 3,8$ & \\
\hline $\mathbf{6 5 +}$ & $62,23 \pm 16,51$ & $16,14 \pm 3,8$ & \\
\hline
\end{tabular}

Table 2. Table of distribution of Se, Zn and Cu by sex, smoking status, exercise status and age.

\section{According to Table 2, Following Results were Obtained for $\mathrm{Zn}$ Levels}

- There was a statistically significant difference was found male individuals and female individuals (p:0.01).

- Statistically individuals significant difference was not found in terms of age distribution between male and values of female individuals (p:0.053).

- Non-smokers were found to have higher amount of Zn, which was statistically significant.

- There is a significant difference between exercise and non-exercise.

\section{According to Table 2, Following Results were Obtained for $\mathrm{Cu}$ Levels}

- No difference was found between groups in terms of sex (p:0.204), but there was a significant difference between age groups (p:0.001). With the advancing age, higher levels of $\mathrm{Cu}$ was observed.

\section{According to Table 2, Following Results were Obtained for Se Levels}

- No difference was found in terms of sex (p:0.192).

- A significant difference was found between the age groups. (p:0.0274).

- There was a significant difference in smoking status. (p:0.025).

- There was a difference between the groups in terms of exercise habits. (p:0.035).

\section{As a Result of Our Study}

Zn Concentration: 16,47 $\mu \mathrm{mol} / \mathrm{L}$. Compared to mean Zn levels in reference textbooks 7-15 $\mu \mathrm{mol} / \mathrm{L}$, our mean results is coherent with the literature.

Cu Concentration: 137,78 $\mu \mathrm{g} / \mathrm{L}$. Compared to mean $\mathrm{Zn}$ levels in reference textbooks 75-155 $\mu \mathrm{g} / \mathrm{L}$, our mean results is coherent with the literature.

Se Concentration: 73,35 $\mu \mathrm{g} / \mathrm{L}$. Compared to mean $\mathrm{Zn}$ levels in reference textbooks 35-135 $\mu \mathrm{g} / \mathrm{L}$, our mean results is coherent with the literature.

\section{Discussion}

Trace elements are fundamental for composition of the organisms but toxic effects of their excessive levels may alter various biological functions. Different opinions have been published in the literature for determining the normal levels of these elements. A reason for these wide range of results is the difficulty of obtaining proper measurements and the interactions of the trace elements between each other. Another reason is the variability of the reference ranges available for these elements.

Determination of the concentration of trace elements in the blood in our study depends to a large extent on the use of reference ranges. Therefore, precise determination of reference ranges becomes important. Previously published studies are summarized in Table 3. 


\section{International Journal of Biochemistry \& Physiology}

\begin{tabular}{|c|c|c|c|c|}
\hline Study & Number of samples & Selenium(Se) $(\mu \mathrm{g} / \mathrm{L})$ & Zinc $(\mathrm{Zn})(\mu \mathrm{mol} / \mathrm{L})$ & Copper $(\mathrm{Cu})(\mu \mathrm{g} / \mathrm{L})$ \\
\hline Farzın, et al. [12] & 115 & $99,10 \pm 21,78$ & $8,90 \pm 1,60$ & $95,00 \pm 20,00$ \\
\hline Kazi, et al. [13] & 120 & $77,00 \pm 13,50$ & $10,20 \pm 2,20$ & - \\
\hline Rukgauer, et al. [2] & 68 & $80,00 \pm 36,00$ & $16,60 \pm 1,00$ & $165,00 \pm 86,00$ \\
\hline Bocca, et al. [14] & 215 & 140,00 & 98,16 & 1036 \\
\hline Bunch, et al. [15] & 50 & $173,74-276,40$ & - & - \\
\hline Hussain, et al. [16] & 450 & - & 24,07 & - \\
\hline Tratnik, et al. [17] & 1084 & 105 & 101,04 & 951 \\
\hline Choi, et al. [18] & 227 & $(120.0-171.8)$ & 8,721 & $(86.3-120.0)$ \\
\hline Estecha, et al. [19] & 327 & 79,5 & - & - \\
\hline Michalska-Mosiej, et al. [20] & 67 & $77,969 \pm 12,73$ & - & - \\
\hline Liu, et al. [21] & 1400 & $39.9-111.6$ & 11,32 & $107.0-362.4$ \\
\hline Ayoglu, et al. [22] & 57 & $100-114$ & $10,7-23,7$ & $100-110$ \\
\hline Sepehri, et al. [23] & 180 & 76,74 & 14,535 & 92,55 \\
\hline Skalnaya, et al. [24] & 128 & $105-164$ & $10,7-22,95$ & $80-155$ \\
\hline Lee, et al. [25] & 167 & $58-234$ & $10,09-16,83$ & $75-145$ \\
\hline Sahebari, et al. [26] & 100 & $90.92 \pm 22.77$ & $13,464 \pm 2,4$ & $1124.21 \pm 315.78$ \\
\hline Our Study & 159 & $73,35 \pm 20,40$ & $16,47 \pm 3,82$ & $73,44 \pm 23,12$ \\
\hline
\end{tabular}

Tablo 3. Comparison of the limit of determination of $\mathrm{Se}, \mathrm{Zn}$ and $\mathrm{Cu}$ with previously published studies.

With the comparison of our sudy with the other studies given in Table 3 . The results below were found.

- Our results are closer to previously reported Se ranges.

- Zinc values are found to be in the optimal range as previously reported

- Our results for copper levels seems to be the lowest in the literature.

In our study, selenium and copper values were lower compared to the other studies. This is due to the fact that nutrient sources rich in selenium and copper are mostly found in seafood. Values obtained in the studies performed in sea bordering areas are higher compared to our study. This result is influenced by the differance of direct fish and sea food (tuna, shrimp, oyster) consumption. Although, compared to other studies our zinc results were in the spesified optimal range, they were found to be lower from some other regions. The reason for this is the low level of zinc in soil and plant analyzes conducted in our country. Zinc levels are known to be decreasing in societies like ours where bread is consumed frequently. Therefore, zinc values were low in laboratory analysis.

Soil quality, content and mineral richness affect the health status of individuals. With the consumption of nutrients grown in the soil, the minerals settle directly in the human body and take part in various metabolic events. A peculiar structure of the soil can lead to differences in human blood in terms of certain values (such as trace elements). The best way to eliminate this difference is to take supplementary nutrients and foodstuffs. Thus, the lack of this elements in humans can be eliminated. It is necessary to raise awareness among people about the consumption of food rich in selenium, zinc and copper elements, which play an important role in the human body. In order to increase the average values of trace elements (selenium, zinc and copper) taken into consideration, it would be beneficial to carry out different studies on enriching food quality.

\section{Conclusion}

In this study, serum selenium zinc and copper values were determined for Tokat province.

Serum selenium and copper levels were within normal reference ranges, while zinc levels were found in high limit ranges. Determining the levels of trace elements necessary for human health is important to decide whether food supplements are needed or not. Determination of the reference values of selenium, copper and zinc trace elements in Tokat province will make a great contribution to the evaluation of these elements. This study will be important in raising awareness about consumption of foods rich in trace elements in individuals with trace element deficiencies. 


\section{International Journal of Biochemistry \& Physiology}

\section{References}

1. Burtis CA, Ashwood ER, Bruns DE (2006) Tietz text book of clinical chemistry and molecular diagnostics. $4^{\text {th }}$ (Edn.), Elsevier Saunders Printed in the United States of America.

2. Rukgauer M, Kleın J, Kruse JJD (1997) Reference Values Fort He Trace Elements Copper, Manganese, Selenium, Andzinc in The Serum/Plasma Of Children Adolescents, And Adults. Journal Of Trace Elements in Medicine and Biology 11(2): 92-98.

3. Dogan S (2009) Atomik Absorpsiyon Spektroskopisi ile Sacta Eser Element Tayininde Farkli ornek Hazırlama Yontemlerinin Karsilastirilmail. Yuksek Lisans Tezi Mersin.

4. Lee YH, Bang ES, Lee HJ, Lee DJ, Ryong KD, Hong J, Myeong LJ (2019) Serum Concentrations of Trace Elements Zinc, Copper, Selenium, and Manganese in Critically Ill Patients. Biological Trace Element Research 188(2): 316-325.

5. Gao S, Jin Y, Unverzagt FW, Liang C, Hall KS, et al. (2012) Selenium Level and Depressive Symptomps in a Rural Elderly Chinese cohort. BMC Psychiatry 12: 72.

6. Laclaustra M, Stranges S, Acien AN, Ordovas JM, Guallar E (2010) Serum selenium and serum lipids in us adults. Atherosclerosis 210(2): 643-648.

7. Lener M, Wiechowska A, Kozlowska A, Kladny J, Muszynska M, et al. (2012) Selenium and the risk of cancers of the colon pancreas and stomach. Hereditary Cancer in Clinical Practice 10: 1-2.

8. Taneli B (2005) Anadolu Toplumunda Zn. Ege Tıp Dergisi 44(1): 1-10.

9. Tanrıverdi MH (2008) Pnomoni Tanısıla Hastaneye Yatırılan 0-2 Yas Arasi Cocuklarda Serum Zn Duzeyi. Uzmanlik Tezi istanbul, pp: 1-62.

10. Tosun E (2009) Determination of Trace Elements and Minerals in Tissues of Some Fruits And Vegetables Used İn Disease Treatment. Master Thesis Malatya.

11. Filippini T, Cilloni S, Malavolti M, Violi F, Malagoli C, et al. (2018) Dietary intake of Cadmium, Chromium, Copper, Manganese, Selenium and Zinc in a Northern
Italy Community. Journal of Trace Elements in Medicine and Biology 50: 508-517.

12. Farzin L, Moassesi ME, Sajadi F, Amiri M, Shems H (2009) Biology Trace Elements Research (129): 3645.

13. Kazi TG, Kolachi NF, Afridi HI, Kazi NG, Arain SS (2012) Effects Of Mineral Supplementation On Liver Cirrhosis Cancer/Cancermalepatients. Biologialtraceelementsresarch 150: 81-90.

14. Bocca B, Madeddu R, Asara Y, Tolu P, Marchal JA, et al. (2011) Assessment of Reference Ranges for Blood Cu, $\mathrm{Mn}$, Se And $\mathrm{Zn}$ in an Selected Italian Population. Journal of Trace Elements in Medicine and Biology (25): $19-26$

15. Bunch DR, Cieslak W, Wang S (2017) Whole Blood Selenium Determination by inductively Coupled Plasma Masss Pectrometry. ClinicalBiochemistry 50(12): 710-713.

16. Hussain W, Mumtaz A, Yasmeen F, Khan SQ, Butt T (2014) Reference Range Of Zinc İn Adult Popülation (20-29 Years) Of Lahore, Pakistan. Pak Journal Medicine Sciencie. 30(3): 545-548.

17. Tratnik JS, Falnoga I, Mazei D, Kocman D, Fajon V, et al. (2019) Results of the First National Human Biomonitoring in Slovenia: Trace Elements in Men and Lactating Women, Predictors Of Exposure And Reference Values. International Journal of Hygiene and Enviromental Health 222(3): 563-582.

18. Choi R, Sun J, Yoo H, Kim S, Young Cho Y, et al. (2016) A Prospective Study of Serum Trace Elements in Healthy Korean Pregnant Women. Nutrients 8(11): 116.

19. Gonzalez EM, Bru PI, Pinedo BA, Trasobares E, Palazon BA, et al. (2017) Relationship Between Serum Selenium, Sociodemographic Variables, Other Trace Elements And Lipid Profile in An Adult Spanish Population. Journal of Trace Elements in Medicine and Biology 43: 93-105.

20. Michalska MM, Socha K, Soroczynska J, Karpinska E, Lazarczyk B, et al. (2016) Selenium, Zinc, Copper, and Total Antioxidant Status in the Serum of Patients with Chronic Tonsillitis. Biological Trace Element Research 173(1): 30-34. 


\section{International Journal of Biochemistry \& Physiology}

21. Liu X, Zhang Y, Piao J, Mao D, Li Y, (2017) Reference Values of 14 Serum Trace Elements for Pregnant Chinese Women: A Cross-Sectional Study in the China Nutrition and Health Survey 2010-2012. Nutrients 9(3): 1-10.

22. Ayoglu H, Sezer U, Akin M, Okyay D, Ayoglu F, et al (2016) Selenium, Copper, Zinc, iron Levels And Mortality İn Patients With Sepsis And Systemic İnflammatory Response Syndrome in Western Black Sea Region, Turkey. Original Article 66(4): 447-452.

23. Sepehri Z, Arefi D, Mirzaei N, Afshari A, Kiani Z, et al. (2018) Changes in Serum Level of Trace Elements in Pulmonary Tuberculosis Patients During AntiTuberculosis Treatment. Journal of Trace Elements in Medicine and Biology 50: 161-166.
24. Skalnaya MG, Skalny AV, Yurasov VV, Demidov VA, Grabeklis AR, et al. (2017) Serum Trace Elements and Electrolytes are Associated with Fasting Plasma Glucose and HbA1c in Postmenopausal Women with Type 2 Diabetes Mellitus. Biological Trace Element Research 177(1): 25-32.

25. Lee HY, Bang ES, Lee JH, Lee JD, Kang DR, et al. (2019) Serum Concentrations of Trace Elements Zinc, Copper, Selenium, and Manganese İn Critically Ill Patients. Biological Trace Element Research 188(2): 316-325.

26. Sahebari M, Ayati R, Mirzaei H, Sahebkar A, Hejazi S, et al. (2016) Serum Trace Element Concentrations in Rheumatoid Arthritis. Biological Trace Element Research June 171(2): 237-245. 